\title{
SPECIES DIVERSITY AND SEASONAL ABUNDANCE OF CERTAIN AQUATIC ARTHROPODS SURVEYED FROM SOME PONDS LOCATED AT THE EL-GHORIEB AREA ASSIUT, EGYPT. \\ Abo-El-Maged,T. M. \\ Plant Protection Dept., Faculty of Agric.,Assiut Univ.,Assiut 71516 Egypt \\ E-mail: tnmn203@yahoo.com
}

\begin{abstract}
The current study focused on certain aquatic arthropods extracted from some ponds located at El-Ghorieb area during two years starting from March, 2011. In the present study, twenty species of aquatic arthropods pertaining to six orders (i.e., Diptera, Hemiptera, Coleoptera, Odonata, Cladocera and Acari) were recorded from some water pools. All the aquatic species increase to enumerate through the spring season and the least numbers were recorded during winter. Autumn and summer were inbetween. The occurrence percentage of each species inside its own order was also calculated. The study showed that the highest proportion of mosquito species with an average ratio of 62.29 and the least was with Odonata with an average of 3.6.
\end{abstract}

Keywords: Aquatic arthropods, species diversity, seasonal abundance, El-Ghorieb ponds.

\section{INTRODUCTION}

Aquatic arthropods play an important role in the food chain and public health in environment. This group of animals include at least 12 orders of insects and others (i.e., Araneae, Acari, Crustaceae). Yet, the large groups of water arthropods are the aquatic insects, of these, 12000 species were counted worldwide, the larval stages of these species are fully aquatic, while adults in many species are terrestrial, or at least air-breathing. The aquatic insects incude: the dragonflies (Odonata); Caddisflies (Trichoptera); stoneflies (Pleoptera); beetles (Coleoptera); bugs (Hemiptera), flies and mosquitoes (Diptera) and mayflies (Ephemeroptera). The scarce numbers of mites and spiders are principally occurred on the water surface (Smith, B.P.1983, Merritt and Cummins, 1996, and Richdardson, 2008).

Aquatic insects are the most diverse arthropod groups occurred almost in every type of aquatic habitat throughout the world including, lakes, highly saline pools, phytotelimata, coastal waters and estuaries, acid peat swamps, groundwater, hot springs and even pools of crude oil seeping from the ground (Yule and Yong, 2004). On the other side, some of insect species, especially the adults of order Diptera are of medical importance such as: mosquitoes and houseflies are the major vectors of a wide range of diseases of human and other animals. Certain aquatic insects are predators either in their larval stages (some stone flies), larval and adult stages (some beetles and dragonflies) and in nymphal and adult stages (some bugs) (Adity et al., 2005; Spangler and Steiner, 2005 and Richardson, 2008).

Mosquitoes are the most important participants in the aquatic arthropods complex in Assiut area (Farghal,1974,1979 and Abo El-Maged, 
2009). The second, important participants in the aquatic arthropods complex is the aquatic natural enemies. The role in the ecological food chain is well recognized by certain aquatic ecologists (Rueda, 2008 and Scudder et al., 2010).

The population density of aquatic mosquitoes are closely related to the numerical density of their natural enemies, but the intensity of predators and their significance are vary greatly among habitat types. The mosquitoe larvae are also habitats diverse (Su and Mulla, 2002).

Numerous species of mosquitoes predators were recorded from different pool habitats. Moreover, the aquatic arthropods play an important role not only in the trophicodynamic of ecosystem but also in the indication of the changes of the quality of water as a result of pollution or degradation because of their high sense ability to such changes (Deepa and Rao, 2007). This study was carried out with the following topics firstly to survey and identify diversity of aquatic arthropods in some pools of El-Ghorieb area, secondly to study the population density of those species during the two years of study, and thirdly to estimate the percentage of occurrence of each species inside its own order.

\section{MATERIALS AND METHODS}

The present work was carried out to study the species composition of some aquatic arthropods (i.e., Mosquitoes, beetles, bugs, dragon flies, water fleas and water mites), in addition to study of the population density of the aquatic arthropod species in El-Ghorieb area during two years starting from March, 2011. The experimental sites chosen for the present study are rather mosaic agro-ecosystem that have been planted with vegetables, field crops and orchards. The selected 12 ponds for the present study are completely free of aquatic plants and algae and far from and organic materials. Samples of ten dips were taken fortnightly through two years starting from March, 2011.

The collected materials were taken from the water pool by using enamel ladle (10 $\mathrm{cm}$ in diameter), wide enamel plate, labeled bottle and gar containing normal water in addition to test tubes (containing formalin) and small droppers in accordance with the known method previously recommended by WHO (1975).

Samples were transferred to the laboratory to for identification using certain taxonomical keys illustrated by Mogi et al. (1999); Impoinvil et al. (2007) and Saba (2008). The number of each species of the aquatic arthropods was recorded in each sample.

The monthly of seasonal abundance of each species during the two studied years was also possible.

Statistical analysis: Data obtained were statistically analyses by using applying linear model (F-test) of MSTATC statistical package software (Anonymous, 1988). Means were compared according to the least significant difference (LSD) with $5 \%$ probability (Steel and Torrie, 1984). Figures were illustrated by using the graphic prism software 5 Microsoft Office Excel 2007 programs. 


\section{RESULTS AND DISCUSSION}

Monthly and seasonal abundance of some aquatic arthropod species inhabiting water pools, El-Ghorieb area, Assiut Governorate during the two studied years starting in March 2011:

Data in Table $(1,2)$ show the monthly and seasonal abundance of aquatic mosquitoes and their predators (Avg. no. individuals/10 dips) throughout two years. The highest densities of aquatic mosquitoes were recorded in April of both years (1291 and 1505 individuals/10 dips) and the lowest ones were recorded in January of the first year (105 individuals) and in February of the second year (103 individuals). It might be observed that spring season exhibited the highest population of aquatic mosquitoes, while winter season seemed to be unfavorable as recorded the lowest population. On the other side, all aquatic predator species gave the same trends as recorded more numbers in the spring season, whereas winter season seemed to be less suitable for these predators' activities except for water mites, where scored less census during the summer season of both years.

Table (1): Seasonal abundance of certain aquatic arthropods (Avg. no. ind./10 dips), in El-Ghorieb area during the period starting from March, 2011 to February, 2012.

\begin{tabular}{|l|c|c|c|c|c|c|c|}
\hline \multirow{3}{*}{ Season } & Month & \multicolumn{3}{|c|}{ Aquatic arthropods } & Avg. no. ind./10 dips) \\
\cline { 3 - 8 } & & $\begin{array}{c}\text { Aquatic. } \\
\text { Mosq. }\end{array}$ & $\begin{array}{c}\text { Aquatic } \\
\text { bug. }\end{array}$ & $\begin{array}{c}\text { Aquatic } \\
\text { beetles }\end{array}$ & $\begin{array}{c}\text { Dragon- } \\
\text { flies }\end{array}$ & $\begin{array}{c}\text { Water } \\
\text { fleas }\end{array}$ & $\begin{array}{c}\text { Aquatic } \\
\text { mites }\end{array}$ \\
\hline \multirow{4}{*}{ Spring } & March & 1199 & 246 & 132 & 42 & 90 & 125 \\
& April & 1291 & 189 & 169 & 45 & 370 & 350 \\
& May & 1485 & 230 & 158 & 30 & 292 & 210 \\
\cline { 2 - 8 } Summer & Mean & 1325 & 222 & 153 & 39 & 251 & 228 \\
\hline \multirow{5}{*}{ Autumn } & June & 1016 & 169 & 183 & 49 & 180 & 13 \\
& July & 910 & 85 & 35 & 11 & 81 & 7 \\
& August & 215 & 102 & 177 & 28 & 3 & 2 \\
\cline { 2 - 8 } & Mean & 547 & 119 & 98 & 29 & 88 & 7 \\
\hline \multirow{4}{*}{ Winter } & Sept. & 945 & 84 & 74 & 6 & 106 & 23 \\
& Oct. & 1115 & 109 & 74 & 23 & 150 & 51 \\
& Nov. & 127 & 165 & 148 & 41 & 80 & 51 \\
\cline { 2 - 8 } & Mean & 729 & 119 & 98 & 23 & 112 & 42 \\
\hline & Dec. & 420 & 103 & 53 & 34 & 36 & 69 \\
& Jan. & 105 & 79 & 28 & 8 & 30 & 58 \\
\cline { 2 - 8 } & Feb. & 289 & 86 & 30 & 3 & 16 & 93 \\
\cline { 2 - 8 } & Mean & 271 & 89 & 37 & 15 & 27 & 73 \\
\hline L.S.D 0.05 for seasons & 22.39 & 19.39 & 23.08 & 2.02 & 1.97 & 0.99 \\
\hline L.S.D 0.05 for month & 19.38 & 16.79 & 19.99 & 1.74 & 1.71 & 0.85 \\
\hline L.S.D 0.05for interaction & 38.77 & 33.58 & 39.97 & 3.49 & 3.42 & 1.71 \\
\hline
\end{tabular}


Table (2): Seasonal abundance of certain aquatic arthropods (Avg. no. ind./10 dips), in El-Ghorieb area during the period from March, 2012 to February, 2013.

\begin{tabular}{|c|c|c|c|c|c|c|c|}
\hline \multirow[b]{2}{*}{ Season } & \multirow[b]{2}{*}{ Month } & \multicolumn{6}{|c|}{ Aquatic arthropods (Avg. no. ind./10 dips) } \\
\hline & & $\begin{array}{l}\text { Aquatic. } \\
\text { Mosq. }\end{array}$ & $\begin{array}{c}\text { Aquatic } \\
\text { bug. }\end{array}$ & $\begin{array}{l}\text { Aquatic } \\
\text { beetles }\end{array}$ & $\begin{array}{c}\begin{array}{c}\text { Dragon- } \\
\text { flies }\end{array} \\
\end{array}$ & $\begin{array}{l}\text { Water } \\
\text { fleas }\end{array}$ & $\begin{array}{c}\text { Aquatic } \\
\text { mites }\end{array}$ \\
\hline \multirow{4}{*}{ Spring } & March & 1319 & 265 & 152 & 36 & 166 & 195 \\
\hline & April & 1501 & 275 & 186 & 19 & 321 & 294 \\
\hline & May & 1346 & 193 & 154 & 25 & 579 & 122 \\
\hline & Mean & 1390 & 244 & 164 & 27 & 355 & 204 \\
\hline \multirow{4}{*}{ Summer } & June & 1089 & 166 & 199 & 55 & 102 & 13 \\
\hline & July & 375 & 115 & 98 & 34 & 107 & 22 \\
\hline & August & 310 & 99 & 43 & 7 & 24 & 56 \\
\hline & Mean & 691 & 126 & 113 & 32 & 68 & 30 \\
\hline \multirow{4}{*}{ Autumn } & Sept. & 792 & 101 & 53 & 15 & 119 & 106 \\
\hline & Oct. & 986 & 116 & 89 & 11 & 98 & 72 \\
\hline & Nov. & 1353 & 235 & 101 & 21 & 112 & 89 \\
\hline & Mean & 1044 & 150 & 81 & 16 & 110 & 89 \\
\hline \multirow{4}{*}{ Winter } & Dec. & 927 & 68 & 26 & 4 & 80 & 43 \\
\hline & Jan. & 743 & 73 & 31 & 3 & 15 & 86 \\
\hline & Feb. & 778 & 32 & 28 & 6 & 15 & 81 \\
\hline & Mean & 816 & 57 & 281 & 4 & 37 & 7 \\
\hline \multicolumn{2}{|c|}{ L.S.D 0.05for seasons } & 15.412 & 9.87 & 9.87 & 1.97 & 9.87 & 4.83 \\
\hline \multicolumn{2}{|c|}{ L.S.D 0.05 for month } & 13.347 & 8.54 & 8.54 & 1.07 & 8.54 & 4.19 \\
\hline \multicolumn{2}{|c|}{ L.S.D 0.05 for interaction } & 26.695 & 17.09 & 17.09 & 3.41 & 17.09 & 8.37 \\
\hline
\end{tabular}

Occurrence percentages of aquatic insect predators, crustacean and mite species:

Data in Table (3) represent the result of identified aquatic arthropods extracted from water pools, in El-Ghorieb village, Assiut Governorate, during 2011 to 2013. Five species of mosquitoes pertaining to three genera of a single family (Culicidae) (viz., Culex pipiens, C. antennatus, C. univittatus, Culiseta sp. and Aedes sp.), ten species of aquatic insect predators belonging to four orders and 9 genera were recorded. Order Coleoptera was represented by three species (Cybister fimbriolatus, Cybister sp. and Dytiscus sp.); Hemiptera (Abedus ovatus, Belostoma sp., Lethocems sp., Sigara sp. and Gerris sp.) and Odonata (Agrion sp. and Cordulia sp.). In addition, to three species of water fleas (Bosmina sp., Acroperus sp. and Alona sp.) and two species of water mites (Arrenaras sp. and Hydrazetes $\mathrm{sp}$.$) .$

The percentages of occurrence of each species within its own order showed that, the individuals of Culex pipiens represented $63.94 \%$ and $61.09 \%$, respectively of the total of individuals of the other species occurred in water ponds of El-Ghorieb village during 2011 and 2013 seasons.

Most of the forementioned mosquitoes and aquatic arthropod predators were also surveyed by certain authors (Farghal, 1974 and 1979 and Abo ElMaged, 2009) in Assiut area, recorded six species of the Culicine mosquitoes 
(C. pipiens, C. antennatus, C. univittatus, C. theleri, A. caspius and Culisetae longiareolate); three species of aquatic beetles (Cybister fimbriolatus, Cubister sp. and Dysticus onrzinalsi); two dragonflies and damselflies (Agrion sp. and Godulia sp.); five species of aquatic bugs (Abedus ovatus, Betostoma sp., Lethems sp., Sigara sp. and Gerris sp.); two species of water mites, (Arena sp. and Hydrozetus sp.); three species of water fleas (Bormia sp., aceopetes sp. and Alona sp.), in addition to species of aquatic arthropods. While, Morsy et al. (2003) surveyed 5 species of mosquitoes in Greater Cairo, Egypt (C. pipiens, C. pusillus, C. perexigus, Culiseta longiareolata and Aedes capsius).

The study of mosquito species and associated aquatic predators were received the collectable of many authors around the world.

Simth and Cook (1991), in North American, Fisher and Schweigmann( 2004,2008) in Argentina, Spangler and Steiner (2005) in Venzuela, Deepa and Roa (2007) in India, Braford et al. (2008) in USA and Others.

Table (3): Occurrence percentages (\%) for each surveyed species of aquatic arthropod in relation to its own order during the two year of study.

\begin{tabular}{|c|c|c|c|c|c|c|}
\hline \multirow{2}{*}{ Order } & \multirow{2}{*}{ Species } & \multicolumn{2}{|c|}{ Occurrence (\%) } & \multicolumn{2}{|c|}{ Total(\%) } & \multirow{2}{*}{ Means } \\
\hline & & $2011 / 2012$ & $2012 / 2013$ & $2011 / 2012$ & $2012 / 2013$ & \\
\hline Diptera & $\begin{array}{l}\text { Culex pipiens } \\
\text { C. antennatus } \\
\text { C. univittatus } \\
\text { Culiseta sp. } \\
\text { Aedes sp. }\end{array}$ & \begin{tabular}{|c|}
63.94 \\
12.45 \\
9.96 \\
8.36 \\
5.29 \\
\end{tabular} & \begin{tabular}{|c|}
79.77 \\
8.2 \\
8.98 \\
5.48 \\
2.57 \\
\end{tabular} & 63.49 & 61.09 & 62.29 \\
\hline Hemiptera & $\begin{array}{l}\text { Abedus oratus } \\
\text { Belostoma sp. } \\
\text { Lethocerus sp. } \\
\text { Sigara sp. } \\
\text { Gerris sp. }\end{array}$ & \begin{tabular}{|l|}
25.38 \\
18.82 \\
13.66 \\
23.44 \\
18.70 \\
\end{tabular} & $\begin{array}{l}35.73 \\
20.25 \\
14.10 \\
17.55 \\
12.37 \\
\end{array}$ & 10.72 & 11.18 & 10.95 \\
\hline Coeloptera & $\begin{array}{l}\text { Cybister } \\
\text { fimbriolatus } \\
\text { Cybister sp. } \\
\text { Dytiscumorginalis }\end{array}$ & $\begin{array}{l}62.21 \\
10.61 \\
27.81\end{array}$ & $\begin{array}{l}69.05 \\
12.16 \\
18.79\end{array}$ & 7.54 & 7.46 & 7.50 \\
\hline Odonata & $\begin{array}{l}\text { Agrion sp. } \\
\text { Cordulia sp. }\end{array}$ & $\begin{array}{l}66.56 \\
33.44\end{array}$ & $\begin{array}{l}58.74 \\
41.53\end{array}$ & 2.08 & 1.52 & 3.60 \\
\hline Crustacea & $\begin{array}{l}\text { Bosmino sp. } \\
\text { Acroperus sp. } \\
\text { Alona sp. }\end{array}$ & $\begin{array}{l}41.28 \\
36.06 \\
22.66\end{array}$ & $\begin{array}{l}39.65 \\
33.14 \\
27.21\end{array}$ & 9.33 & 11.17 & 10.25 \\
\hline Acari & $\begin{array}{l}\text { Arrenurus sp. } \\
\text { Hydrozetes sp. }\end{array}$ & $\begin{array}{l}66.08 \\
33.94\end{array}$ & $\begin{array}{l}74.64 \\
25.36\end{array}$ & 6.84 & 7.58 & 7.21 \\
\hline
\end{tabular}


The correlation coefficient ( $r$ ) between aquatic stages of mosquitoes versus their aquatic predators are summarized in Table (4).

Statistical analysis of data showed no significant correlations $(0013,0.0231,0.262,0.321,0.081)$ between the average numbers of aquatic mosquitoes versus the mean numbers of their aquatic arthropods (bugs beetles, dragonflies, waterfleas and water mites in the first year. In the second year, highly significant correlation with aquatic bug (0.968), positive significant was recorded with aquatic beetles, aquatic fleas, aquatic metes $(0.870,0.721$ and 0.846$)$ respectively. While no significant correlation was recorded with Odonata.

Table (4): Simple correlation coefficient $(r)$ between aquatic stages of mosquitoes versus their aquatic arthropods (insects, crustaceae and mites).

\begin{tabular}{|c|c|c|c|c|c|c|c|}
\hline No. & Species & 1 & 2 & 3 & 4 & 5 & 6 \\
\hline \multicolumn{8}{|c|}{$2011 / 2012$} \\
\hline 1 & $\begin{array}{c}\text { Aquatic } \\
\text { mosquito }\end{array}$ & - & - & - & - & - & - \\
\hline 2 & Aquatic bugs & 0.013 & - & - & - & - & - \\
\hline 3 & $\begin{array}{l}\text { Aquatic } \\
\text { beetles }\end{array}$ & 0.0231 & $0.9774^{\star *}$ & - & - & - & - \\
\hline 4 & Odonata & 0.262 & $0.905^{*}$ & $0.923^{*}$ & - & - & - \\
\hline 5 & Aquatic flies & 0.321 & 0.805 & $0.875^{*}$ & 0.636 & - & - \\
\hline 6 & Aquatic mites & 0.081 & $0.998^{\star \star}$ & $0.868^{\star *}$ & $0.924^{*}$ & 0.820 & - \\
\hline \multicolumn{8}{|c|}{$2012 / 2013$} \\
\hline 1 & $\begin{array}{c}\text { Aquatic } \\
\text { mosquito }\end{array}$ & - & - & - & - & - & - \\
\hline 2 & Aquatic bugs & $0.968^{\star *}$ & - & - & - & - & - \\
\hline 3 & $\begin{array}{l}\text { Aquatic } \\
\text { beetles }\end{array}$ & $0.870^{*}$ & $0.931^{*}$ & - & - & - & - \\
\hline 4 & Odonata & 0.623 & 0.642 & $0.858^{*}$ & - & - & - \\
\hline 5 & Aquatic fleas & $0.721^{*}$ & 0.820 & 0.633 & 0.147 & - & - \\
\hline 6 & Aquatic mites & $0.846^{*}$ & $0.946^{* *}$ & $0.858^{*}$ & 0.474 & $0.940^{* *}$ & - \\
\hline
\end{tabular}

In general, mosquito populations are regulated by certain factors including adverse conditions, shortage of food supply, aquatic parasites, and predators (Service, 1973 and Shaalan et.al.2006). However, interaction of factors such as nutrition habitat dehydration, physical features and social interactions influence the distribution and aggregation patterns of mosquito habitats (Impoinvil et al., 2007).

The most aquatic insects associated with immature stages of mosquitoe are belonged to the orders: Coleoptera, Hemiptera, Odonata and Diptera in addition to Crustacea and Acari. Fisher and Schweigmann (2008) found six mosquito species associsted with 23 insect predators in temporary rain pools in Argentina. Similar investigation was recorded by many authors in Egypt (Morsy et al., 2003 and Abo El-Maged, 2009) who recorded that the most aquatic insects associated with immature stages of mosquito are belong 
to orders: Odonata, Hemiptera, Coleoptera and Diptera. Generalist predators that feed on a broad range of prey species are polyphagous, while specialists predatory are oligophagous. Although most predators of mosquitoes tend to be generalists. In the present study the most important aquatic predators recorded in association with mosquito immature stages were aquatic beetles (Dytiscidae), aquatic bugs (Belostomatidae, Corixidae and Gerridae), dragonflies and mayflies (Coenagriidae and Cordulfidae) wholly in agreement with data obtained by certain authors (i.e., Das et al., 2005; Dehghani et al., 2007; Deepa and Roa, 2007 and Caillouët et al., 2008).

\section{REFERENCES}

Abo Elmaged, T.M.(2009).Ecological and Toxicological studies on some aquatic arthropods in Assiut area. Ph.D Dep. Plant. protect. Fact. Agric., Assiut Uni. Assiut Egypt.

Adity, G., Bhattacharyya, S., Kundu, N. and Saha, G.K. 2005. Frequencydependent prey-selection of predacious water bugs on Armigeres subalbatus immatures. J Vect Borne Dis. 42: 9-14.

Anonymous, (1988). "MSTATC" Micro-computer Statistical Programme. Michigan State Univ. of Agriculture, Michigan Lansing, USA.

Bradford C.M., Gellido W. and Presley S.M. (2008). Survey of mosquito fauna in lubbock county, Texas. Journal of the American Mosquito Control Association, 24(3):453-456

Caillouët KA, Carlson JC, Wesson D. and Jordan F.(2008).Colonization of abandoned swimming pools by larval mosquitoes and their predators following Hurricane Katrina. J Vect. Ecol. 33(1):166-72

Das P.K., Sivagnaname, P.K., and Amalraj, D.D. (2005). Population interactions between Culex vishnui mosquitoes and their natural enemies in Pondicherry, India. J. of Vect. Ecol. 31 (1): 84-88

Deepa, J. and Rao C. (2007). Aquatic Hemiptera of pocharam lake, Andhra Pradesh. 2005, Print Journal 22 (12): 2937-2939.

Dehghani R, Miranzadeh MB, Yosefzadeh M and Zamani S. (2007). Fauna aquatic insects in sewage maturation ponds of Kashan University of Medical Science 2005. J Biol. Sci. 10(6):928-3

Farghal, A.I. (1974). Studies on Culicine mosquitoes in Assiut area. M.Sc. Thesis, Dep., Plant Protect. Fac. Agric., Assiut Univ. Assiut Egypt.

Farghal, A.I. (1979). Recent Trends in Culicine Mosquitoes Control. Ph.D. Thesis, Dep., Plant Protect. Fac. Agric., Assiut Univ. Assiut Egypt.

Fisher, S. and N. Scheweigmmann. (2004). Culex mosquitoes in temporary urban rain pools; seasonal dynamics in relation to environmental variables. J.Vect. Ecol. 29:365-373

Fisher S. and Schweigmann N. (2008). Association of immature mosquitoes and predatory insects in urban rain pools. J. Vect. Ecol. 33(1):46-55.

Impoinvil D.E. $\square$, Keating J., Mbogo C.M., Potts M.D.Chowdhury R.R., and Beier J.C. (2007). Abundance of immature Anopheles and culicines (Diptera: Culicidae) in different water body types in the urban environment of Malindi, Kenya. J. of Vect. Ecol. 33 (1): 107-116 
Merritt, R.W. and K.W. Cummins. (1996). An Introduction to the Aquatic Insects of North America. 3rd ed. Kendall Hunt, Dubuque, IA.

Mogi, M., Memah, V., Miyagi, I., Toma, T. and Sembel, D.T. (1995). Mosquito (Diptera: Culicidae) and predator abundance in irrigated and rain fed rice fields in north Sulawesi, Indonesia. J. Med. Entomol. 32 (3) : 361367.

Morsy, T.A.; N.M. Khalil; F.S.M. Habib and N.A.M. El-Laboudy. (2003). Culex mosquito larvae in greater Cairo, Egypt. J. Society of Parasitology, 33 (3): 717-732.

Richardson, J. S.(2008). Aquatic arthropods and forestry: effects of large scale land use on aquatic systems in Nearctic temperate regions.Can. Entomol. 140: 495-509

Rueda, L. M. (2008).Global diversity mosquitoes (Insecta : Culicidae ) in freshwater . Hydrobiologia.595: 477-487.

Saba, R. M. (2008). Studies on some species of Culicine Mosquito in Assiut Governorate. M.Sc. Dep. Plant Protect. Fact. Agric. Al-Azhar Uni. Assiut .

Scudder, G. G. E., Alperyn, M. A. and Roughley, R. E.,(2010). Aquatic Hemiptera of the prairie Grasslands and parkland In Arthropods of Canadian Grasslands (volume 1) in : J. D. Shorthouse and k. D. Floate (ed) Ecology and Interactions in Grassland Habitats .Biological Survey of Canada. Pp 303-323.

Service, M. (1973). Mortalities of the larvae of Anopheles gambiae Giles complex and detection of predators by precipitin test. Bull. Entomol. Res. 62: 359-369

Shaalan E., Canyon, D.; Muller R.Younes M., Abdel-Wahab H., and Mansour A. (2006). A mosquito predator survey in Townsville, Australia, and an assessment of Diplonychus sp. and Anisops sp. predatorial capacity against Culex annulirostris mosquito immatures. J. of Vect. Ecol. 32 (1): 16-21.

Service, M. (1973). Mortalities of the larvae of Anopheles gambiae Giles complex and detection of predators by precipitin test. Bull. Entomol. Res. 62: 359-369

Smith BP. (1983). The potential of mites as biological control agents of mosquitoes. In: Hoy MA, Cunningham GL, Knutson L, eds. Biological control of pest by mites Special Publ Univ Calif No. 3304. 185.

Smith IM, Cook DR. (1991). Water mites. In: Thorp JH, Covich AP, eds. Ecology and classification of North American Freshwater Invertebrates. San Diego, CA:Academic Press Inc. 1191pp.

Spangler P.J. and Steiner W.E. (2005). A new aquatic beetle family, Meruidae, from Venezuela (Coleoptera: Adephaga). Systematic Entomol. 30:339-357

Steel, R.G.D. and J.H. Torrie, (1984). Principles and Procedures of Statistics. McGraw Hill Book Co., Tokyo, Japan

Su, T., and Mulla, M.S., (2002). Introduction and establishment of tadpole shrimp Triops newberryi (Notostraca: Triopsidae) in a date garden for biological control of mosquitoes in Coachella Valley, southern California. J. Vect. Ecol. 27 (1), 138-148. 
WHO., (1975). Manual on Practical Entomology in Malaria Part II (Methods and Terminology). WHO, Geneva, p. 78.

Yule, C. M. and Yong H. S. (2004). Freshwater Invertebrates of the Malaysian Region .Academy of Sciences Malaysia, Kuala Lumpur Malaysia.

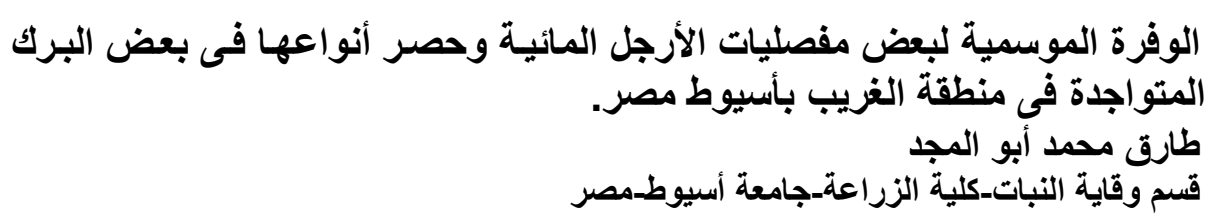

أجريت الدراسة على بعض مفصليات الأرجل المائية الموجودة فى بعض البرائر فيرك في منطقة

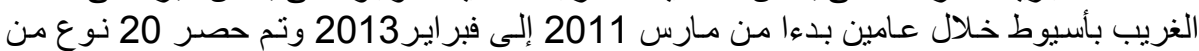

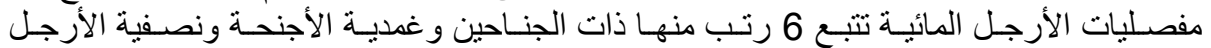

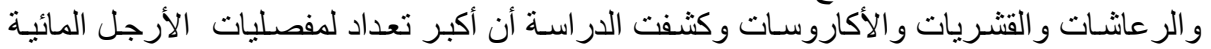

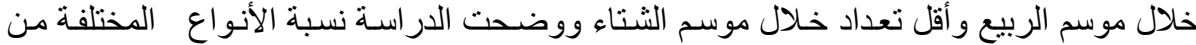

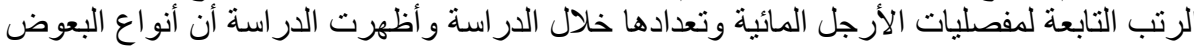

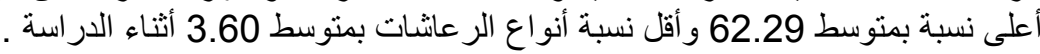

